\title{
OPEN Author Correction: Evidence of trans-generational developmental modifications induced by simulated heat waves in an arthropod
}

\author{
A. Walzer, H. Formayer \& M.-S. Tixier \\ Correction to: Scientific Reports https://doi.org/10.1038/s41598-020-61040-z, published online 05 March 2020
}

A reference to the study describing the design of the cages was omitted in this Article. This paper is cited as Reference 1 below, and should appear in the text of the Article, in the Methods subsection 'Rearing and experimental units', where,

"Lockable acrylic cages were used as experimental units with cylindrical circular chambers (Ø $15 \mathrm{~mm}, 3 \mathrm{~mm}$ high). The backsides of the chambers were closed with fine gaze, the front sides were closed with a microscope slide fixed with metallic clips (Fig. 1). Water was provided by a wet filter paper fixed on the backside of the cage, reaching into a cup with tap water."

should read:

"Lockable acrylic cages were used as experimental units with cylindrical circular chambers (Ø $15 \mathrm{~mm}, 3 \mathrm{~mm}$ high). The backsides of the chambers were closed with fine gaze, the front sides were closed with a microscope slide fixed with metallic clips (Fig. 1). Water was provided by a wet filter paper fixed on the backside of the cage, reaching into a cup with tap water ${ }^{1}$."

\section{References}

1. Schausberger, P. Inter- and intraspecific predation on immatures by adult females in Euseius finlandicus, Typhlodromus pyri and Kampimo dromus aberrans (Acari: Phytoseiidae). Exp. Appl. Acarol 21, 131-150 (1997).

(c) Open Access This article is licensed under a Creative Commons Attribution 4.0 International License, which permits use, sharing, adaptation, distribution and reproduction in any medium or format, as long as you give appropriate credit to the original author(s) and the source, provide a link to the Creative Commons license, and indicate if changes were made. The images or other third party material in this article are included in the article's Creative Commons license, unless indicated otherwise in a credit line to the material. If material is not included in the article's Creative Commons license and your intended use is not permitted by statutory regulation or exceeds the permitted use, you will need to obtain permission directly from the copyright holder. To view a copy of this license, visit http://creativecommons.org/licenses/by/4.0/.

(C) The Author(s) 2020 